\title{
Analytical Methods INAA and PIXE Applied to Characterization of Airborne Particulate Matter in Bandung, Indonesia
}

\author{
D.D. Lestiani ${ }^{\star}$ and M. Santoso \\ Center for Nuclear Technology of Material and Radiometry, National Nuclear Energy Agency \\ Tamansari 71, Bandung 40132, Indonesia.
}

\section{ARTICLE INFO}

Article history:

Received 20 November 2010

Received in Revised form 09 August 2011

Accepted 15 August 2011

Keywords:

Elemental characterization

INAA

PIXE

Particulate matter

Air pollution

\begin{abstract}
A B S T R A C T
Urbanization and industrial growth have deteriorated air quality and are major cause to air pollution. Air pollution through fine and ultra-fine particles is a serious threat to human health. The source of air pollution must be known quantitatively by elemental characterization, in order to design the appropriate air quality management. The suitable methods for analysis the airborne particulate matter such as nuclear analytical techniques are hardly needed to solve the air pollution problem. The objectives of this study are to apply the nuclear analytical techniques to airborne particulate samples collected in Bandung, to assess the accuracy and to ensure the reliable of analytical results through the comparison of instrumental neutron activation analysis (INAA) and particles induced X-ray emission (PIXE). Particle samples in the $\mathrm{PM}_{2.5}$ and $\mathrm{PM}_{2.5-10}$ ranges have been collected in Bandung twice a week for 24 hours using a Gent stacked filter unit. The result showed that generally there was a systematic difference between INAA and PIXE results, which the values obtained by PIXE were lower than values determined by INAA. INAA is generally more sensitive and reliable than PIXE for $\mathrm{Na}, \mathrm{Al}, \mathrm{Cl}, \mathrm{V}, \mathrm{Mn}, \mathrm{Fe}, \mathrm{Br}$ and I, therefore INAA data are preffered, while PIXE usually gives better precision than INAA for $\mathrm{Mg}, \mathrm{K}, \mathrm{Ca}$, Ti and $\mathrm{Zn}$. Nevertheless, both techniques provide reliable results and complement to each other. INAA is still a prospective method, while PIXE with the special capabilities is a promising tool that could contribute and complement the lack of NAA in determination of lead, sulphur and silicon. The combination of INAA and PIXE can advantageously be used in air pollution studies to extend the number of important elements measured as key elements in source apportionment.
\end{abstract}

(C) 2011 Atom Indonesia. All rights reserved

\section{INTRODUCTION}

Urbanization and industrial growth have deteriorated air quality and are major cause to air pollution. The problems associated with air particulate matter are of great concern in many developing countries especially in large cities. Particulate matter has adverse health effects, affecting both the respiratory and cardiovascular systems $[1,2]$. Fine and ultra-fine particles penetrate deeply into the lungs and can remain there for a substantial time. The WHO estimated the global attributable mortality risk due to particle urban air pollution about more than 800,000 per year deaths per year due to particle indoor air pollution in urban and rural areas [3]. They also have serious influence on climate forcing, global warming and visibility

\footnotetext{
* Corresponding author.

E-mail address: diahdwi@batan.go.id
}

$[3,4]$. In Indonesia, there are some routine air pollution monitoring, but the focus is still in total suspended particulate (TSP) or $\mathrm{PM}_{10}$ (particles with aerodynamic diameters less than $10 \mu \mathrm{m}$ ). The long term published data on $\mathrm{PM}_{2.5}$ (particles with aerodynamic diameter less than $2.5 \mu \mathrm{m}$ ) concentrations and compositions of airborne particulate matter is still scarce. Kim Oanh et al., (2006) presented summaries of $\mathrm{PM}_{2.5}$ and $\mathrm{PM}_{10}$ in six cities in Asia, namely Bandung (Indonesia), Bangkok (Thailand), Beijing (China), Chennai (India), Manila (Phillippines), and Hanoi (Vietnam) [5]. Other also reported on the composition and source apportionment of fine and coarse particle samples collected in Bandung and Lembang, Indonesia between 2002 and 2004 [6].

The source of air pollution must be known quantitatively i.e elemental characterization in order to design the appropriate air quality management. The suitable methods for airborne particulate matter 
characterization are hardly needed to solve the air pollution problem. For this reason, the nuclear analytical techniques such as instrumental neutron activation analysis (INAA) and particle induced $\mathrm{X}$-ray emission (PIXE) are widely used to analysis the filter samples of airborne particulate matters. Nuclear techniques have been applied to the characterization of particulate matter from air pollution in around the world [4-12]. Their high capabilities, simultaneous measurement, multi-elemental, high sensitivity, short analysis time and non destructive properties make them ideal for this type of work. The air particulate samples in filter may only contain a total sample mass of $100 \mu \mathrm{g}$, thus providing an extremely small sample for analysis by other more conventional method. Furthermore, the large data sets generated have been used for apportionment of particulate matter sources which are keys to effective understanding, control and management of particulate matter air pollution. Based on this fact, the characterization of airborne particulate matter becomes increasingly important.

The objectives of this study is to apply the nuclear analytical techniques to airborne particulate samples collected in Bandung, to assess the accuracy and to ensure the reliable of analytical results through the comparison of instrumental neutron activation analysis (INAA) and particles induced X-ray emission (PIXE). This step is important and extremely useful for quality assurance and quality control especially when it becomes to assembly the data sets for source apportionment, it combined elemental results obtained from two independent techniques [6]. This work focused on elements that are detected well in both techniques in fine particulate matter- $\mathrm{PM}_{2.5}$. The period of samples 2004-2005 was chosen, since it was considered that this time period almost has similar environmental condition for long term data and close to each samples year set. The data sets then were combined to be used in source apportionment later. Since in each year data sets were analyzed with different techniques and due to there was no same samples analyzed with both techniques, the comparison was focused on the each technique accuracy, limit detection and some limitations.

\section{EXPERIMENTAL METHODS}

Air particulate samples have been collected in Bandung during 2004-2005 twice a week for 24 hours using a Gent stacked filter unit sampler in two size fractions of $<2.5 \mu \mathrm{m}$ (fine) and 2.5 to $10 \mu \mathrm{m}$ (coarse) [13]. The fine particulate matter$\mathrm{PM}_{2.5}$ samples were collected on $0.4 \mu \mathrm{m}$ pore nuclepore polycarbonate filters, while the coarse fraction samples were collected on an $8.0 \mu \mathrm{m}$ pore nuclepore polycarbonate filters. Sampling was conducted at a flow rate of 15 to $18 \mathrm{~L} / \mathrm{min}$ and a total of 128 samples were collected. Airborne particulate samples were stored in clean polyethylene bag and placed in clean room at the relative humidity below $60 \%$ and temperature of $18-25^{\circ} \mathrm{C}$ for mass stabilization. The samples collected in 2004 were analyzed for elemental concentration by INAA. The irradiation procedure and the counting have been written elsewhere [14]. Method validation was conducted using Standard Reference Material-SRM National Institute Standard of Technology NIST 1648 airborne particulate matter. The NIST standard reference material SRM 1648 airborne particulate matter were analyzed in the same experimental conditions used in the sample analysis as method validation to evaluate the precision and accuracy of the results by INAA. Elemental analysis of samples collected in 2005 was performed using PIXE at the Institute of Geological and Nuclear Sciences (GNS), New Zealand. Samples were mounted on the positioning system and irradiated with $2.5 \mathrm{MeV}$ proton beam in a vacuum chamber. The beam current was $10 \mathrm{nA}$ and beam was accumulated for a preset charge of $60 \mu \mathrm{C}$. Emitted X-rays were detected by $\mathrm{Si}(\mathrm{Li}) \mathrm{X}$-ray detector located at $135^{\circ}$ angle according to incident proton beam. The X-ray spectra were analyzed using the computer code GUPIX [15]. Calibration of the PIXE system was performed by irradiating the suitable MicroMatter thin target standards.

\section{RESULTS AND DISCUSSION}

The ratios of determined and certified value for SRM NIST 1648 are presented in Fig. 1. These analysis results had a good agreement with the value quoted in the NIST certificate.

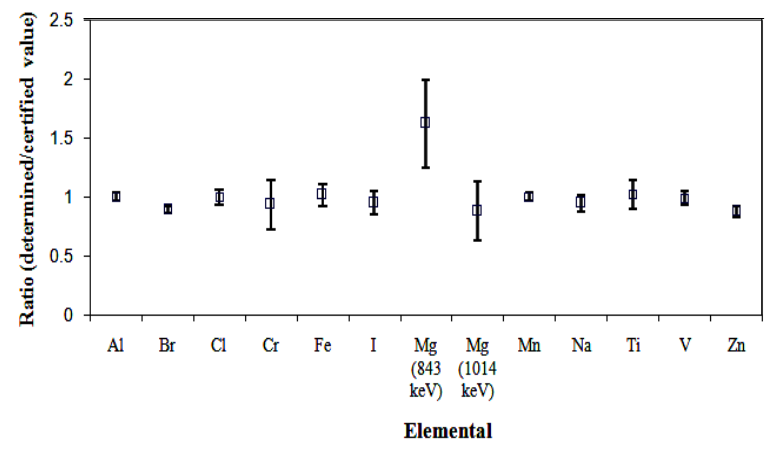

Fig. 1. Ratio of determined/certified value of SRM NIST 1648 airborne particulate matter. 
Zinc determined by ${ }^{65} \mathrm{Zn} \quad(1115 \mathrm{keV})$ is systematically lower than the certified value, the ratio is 0.88 with error $5 \%$. This happened due to the overlapping with Eu peak in $1120 \mathrm{keV}$, nevertheless it is still in permitable range, and it may be said that this result is still good agreement with the certified value. For $\mathrm{Mg}$, the mean ratio is 1.63 and error is $38 \%$. This large statistical error on peak areas from ${ }^{27} \mathrm{Mg}(843 \mathrm{keV})$ was happened due to the competing ${ }^{27} \mathrm{Al}(\mathrm{n}, \mathrm{p}){ }^{27} \mathrm{Mg}$ nuclear interference reaction as well as the strong overlapping peak of $846.7 \mathrm{keV}$ from ${ }^{55} \mathrm{Mn}(\mathrm{n}, \gamma){ }^{56} \mathrm{Mn}$ reaction. At the measurement, good resolution was not achieved between these two photopeaks, therefore the less sensitive $1014 \mathrm{keV}$ photopeak of $\mathrm{Mg}$ was used. The ratio of $\mathrm{Mg}$ $1014 \mathrm{keV}$ was 0.88 with error $25 \%$. Except for $\mathrm{Mg}$ $843 \mathrm{keV}$, most elements i.e $\mathrm{Al}, \mathrm{Br}, \mathrm{Cl}, \mathrm{Cr}, \mathrm{Fe}, \mathrm{I}, \mathrm{Mg}$ (1014 keV), Mn, Na, Ti, V and $\mathrm{Zn}$ are in good agreements with the certified values. The accuracy of PIXE could not be ascertained due to the nonavailability of adequate reference materials.

Table 1. Detection limit in $\mathrm{ng} / \mathrm{m} 3$ for elements that were measured by INAA and PIXE.

\begin{tabular}{ccc}
\hline Element & NAA & PIXE \\
\hline $\mathrm{Al}$ & 0.22 & 1.32 \\
$\mathrm{As}$ & 0.002 & 0.56 \\
$\mathrm{Br}$ & 1.18 & 0.35 \\
$\mathrm{Ca}$ & 5.00 & 0.53 \\
$\mathrm{Cl}$ & 0.07 & 0.70 \\
$\mathrm{Co}$ & 0.003 & 0.26 \\
$\mathrm{Cr}$ & 0.10 & 0.13 \\
$\mathrm{Cu}$ & 2.20 & 0.06 \\
$\mathrm{Fe}$ & 2.00 & 0.10 \\
$\mathrm{Hg}$ & 0.17 & 0.23 \\
$\mathrm{I}$ & 0.07 & 1.81 \\
$\mathrm{~K}$ & 4.00 & 0.55 \\
$\mathrm{Mg}$ & 6.43 & 2.62 \\
$\mathrm{Mn}$ & 0.01 & 0.11 \\
$\mathrm{Na}$ & 0.11 & 13.47 \\
$\mathrm{Sb}$ & 0.01 & 0.02 \\
$\mathrm{Sc}$ & 6.00 & 0.51 \\
$\mathrm{Se}$ & 0.03 & 0.15 \\
$\mathrm{Sm}$ & 0.001 & 0.01 \\
$\mathrm{Ti}$ & 3.07 & 0.23 \\
$\mathrm{~V}$ & 0.01 & 0.18 \\
$\mathrm{Zn}$ & 0.44 & 0.09 \\
\hline & & \\
\hline
\end{tabular}

In INAA and PIXE, the detection limits highly depend on the presence of other elements in the samples because of their impact on the Compton $\gamma$-ray background in INAA or on spectral interferences mainly in PIXE. As a consequence, the detection limits vary from one sample to other sample [16]. The detection limits for some elements observed by both techniques are presented in Table 1. For the elements that were detected below or near their detection limit in the majority of samples either by one or both techniques, INAA gave more significant results for $\mathrm{As}, \mathrm{Cl}, \mathrm{Co}, \mathrm{I}, \mathrm{Mn}$, $\mathrm{Na}, \mathrm{Sm}$ and V. On the other hand, PIXE was more sensitive than INAA for $\mathrm{Cu}, \mathrm{Fe}, \mathrm{K}, \mathrm{Ti}$, Sc and $\mathrm{Zn}$.

The elemental concentration in fine air particulate matter by NAA and PIXE are presented in Fig. 2 and Fig. 3. The horizontal lines in the box denote the $25^{\text {th }}, 50^{\text {th }}$, and $75^{\text {th }}$ percentile values. The error bars denote the $5^{\text {th }}$ and $95^{\text {th }}$ percentile values. The two symbols below the $5^{\text {th }}$ percentile error bar denote the $0^{\text {th }}$ and $1^{\text {st }}$ percentile values. The two symbols above the $95^{\text {th }}$ percentile error bar denote the $99^{\text {th }}$ and $100^{\text {th }}$ percentiles. The plus symbol in the box denotes the mean data.

More than 35 elements such as $\mathrm{Ag}, \mathrm{Al}$, As, $\mathrm{Ba}, \mathrm{Br}, \mathrm{Ca}, \mathrm{Ce}, \mathrm{Cl}, \mathrm{Co}, \mathrm{Cr}, \mathrm{Cs}, \mathrm{Cu}, \mathrm{F}, \mathrm{Ga}, \mathrm{Ge}, \mathrm{Hf}$, $\mathrm{Hg}, \mathrm{I}, \mathrm{K}, \mathrm{La}, \mathrm{Mg}, \mathrm{Mn}, \mathrm{Mo}, \mathrm{Na}, \mathrm{Ni}, \mathrm{P}, \mathrm{Pb}, \mathrm{Rb}, \mathrm{S}, \mathrm{Sb}$, $\mathrm{Sc}, \mathrm{Se}, \mathrm{Si}, \mathrm{Sm}, \mathrm{Sr}, \mathrm{Ti}, \mathrm{V}$ and $\mathrm{Zn}$ were determined altogether by INAA and PIXE, but in this paper only the elemental determined by both technique such as $\mathrm{Al}, \mathrm{Br}, \mathrm{Ca}, \mathrm{Cl}, \mathrm{Cr}, \mathrm{Fe}, \mathrm{I}, \mathrm{K}, \mathrm{Mg}, \mathrm{Mn}, \mathrm{Na}$, Ti, $\mathrm{V}$ and $\mathrm{Zn}$ were compared. From the observation of the distribution of each element analyzed by INAA and PIXE as shown in Fig. 2 and Fig. 3, it can be seen that for $\mathrm{Br}$ and $\mathrm{Cl}$ concentration obtained by PIXE were lower than the distribution by INAA. Loss of these elements was already observed and discussed by other authors and several possible explanations have been given [17]. Most likely these elements were volatized to a certain extend during the PIXE bombardment of the samples [16]. For Fe, the values obtained by PIXE are lower than those determined by INAA. Zeisler et al. determined Fe concentration by INAA and PIXE and obtained lower concentration by PIXE especially in the samples with large $\mathrm{Fe}$ amounts [17]. Toro et al. reported Fe concentration analyzed by PIXE and INAA which showed that PIXE results were lower more than half-one third than INAA results [18]. Our results for $\mathrm{Fe}$ from PIXE also has a lower value than by INAA. Other elements such as $\mathrm{Al}, \mathrm{Ca}, \mathrm{Cr}$, $\mathrm{Mn}, \mathrm{Na}$ and $\mathrm{Zn}$ were almost in the within range for both technique, with ratio of PIXE/NAA were $0.74-1.11$. There is a systematic difference between INAA and PIXE results with the values from PIXE lower than values determined by INAA $[18,19,20]$. This could be due to a non homogenous distribution of the mass on the surface of filter, to which PIXE is very sensitive. For higher concentrations in fine fraction, the values tend to differ more, this could be 
probably because PIXE is just analysing on surface while INAA analyses the total. Based on the sensitivity of each elements, accuracy and the systematic difference between both techniques, INAA was good for $\mathrm{Na}, \mathrm{Al}, \mathrm{Cl}, \mathrm{V}, \mathrm{Mn}, \mathrm{Fe}, \mathrm{Br}$ and $\mathrm{I}$, therefore INAA data are preffered, while PIXE gave better precision than INAA for $\mathrm{Mg}, \mathrm{K}, \mathrm{Ca}, \mathrm{Ti}$ and $\mathrm{Zn}$. Besides that, PIXE has complement the lack of INAA in determination of $\mathrm{Pb}, \mathrm{S}$ and $\mathrm{Si}$ which are not possible to be determined by INAA. $\mathrm{Pb}$ is due to very low neutron cross section, while $\mathrm{S}$ and $\mathrm{Si}$ is best detected by $(n, p)$ reaction and greatly improved by using epithermal neutrons. These elements are key elements for source apportionment to find the correlation related to industial emissions, vehicles emissions and the crustal sources.

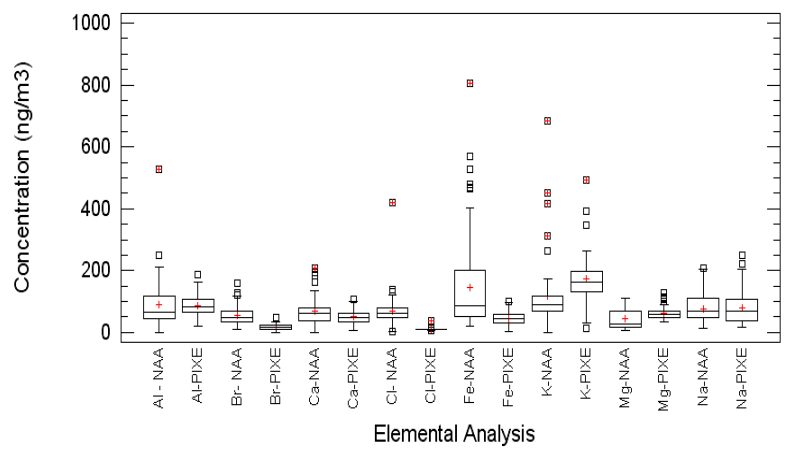

Fig. 2. Distribution of $\mathrm{Al}, \mathrm{Br}, \mathrm{Ca}, \mathrm{Cl}, \mathrm{Fe}, \mathrm{K}, \mathrm{Mg}$ and $\mathrm{Na}$ concentrations analyzed by INAA and PIXE.

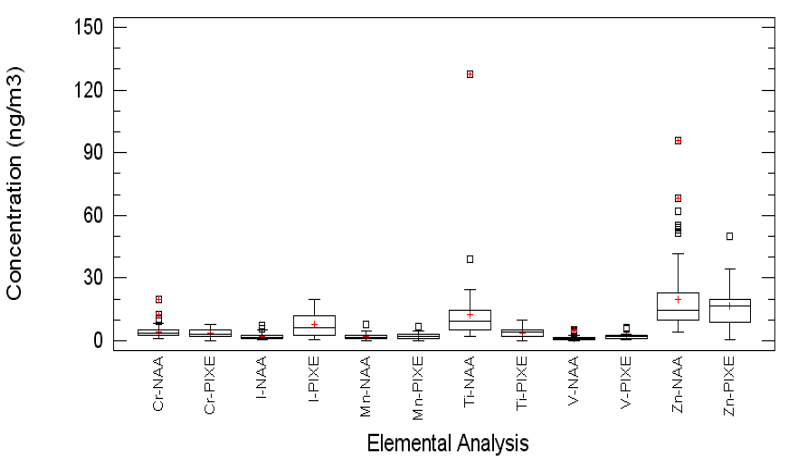

Fig. 3. Distribution of $\mathrm{Cr}, \mathrm{I}, \mathrm{Mn}, \mathrm{Ti}, \mathrm{V}$ and $\mathrm{Zn}$ concentrations analyzed by INAA and PIXE.

Combined the data sets using different techniques approach not only provided results for a large number of elements, but for several elements also provided from two independent techniques. The combination of INAA and PIXE can advantageously be used in air pollution studies to extend the number of important elements measured as key elements in source apportionment. On the other hand, PIXE has wide range application in other field study, it should be considered to widely open the possibility for ion beam analysis development in Indonesia.

\section{CONCLUSION}

The accuracy of INAA for characterization of air particulate matter on polycarbonate filter collected in Bandung, Indonesia is in good agreement with related standard reference materials. The result showed that INAA is generally more sensitive and reliable than PIXE for $\mathrm{Na}, \mathrm{Al}, \mathrm{Cl}, \mathrm{V}, \mathrm{Mn}, \mathrm{Fe}, \mathrm{Br}$ and $\mathrm{I}$, therefore INAA data are preffered, while PIXE usually gives better precision than INAA for $\mathrm{Mg}, \mathrm{K}, \mathrm{Ca}, \mathrm{Ti}$ and $\mathrm{Zn}$. Nevertheless, both techniques provide reliable results and complement to each other. This study has shown that INAA is still a prospective method, while PIXE with the special capabilities is a promising tool that could contribute and complement the lack of INAA in determination of lead, sulphur and silicon. The combination of INAA and PIXE can advantageously be used in air pollution studies to extend the number of important elements measured as key elements in source apportionment. PIXE wide range application in other field of study should be considered to widely open the possibility of ion beam analysis development in Indonesia.

\section{ACKNOWLEDGMENT}

The authors would like to acknowledge for all the staffs in Radiometry Analytical Techniques group in National Nuclear Energy Agency of Indonesia (BATAN) Bandung. These research is supported by International Atomic Energy Agency (IAEA) and BATAN.

\section{REFERENCES}

1. D.W. Dockery, C.A. Pope, X. Xu, J.D. Spengler, J.H. Ware, M.E. Fay, B.G. Ferris and F.E. Speizer, J. Med. 329 (1993) 1753.

2. K. Katouyanni, Occup. Environ. Med. 62 (2005) 432.

3. D.L. Albritton and L.G. Meira Filho, IPCC Technical Summary (2001).

4. D.D. Cohen, D. Gorton, E. Stelcer and O. Hawas, Radiat. Phys. Chem. 71 (2004) 759. 
5. N.T. Kim Oanh, N. Upadhayay and Y.H. Zhuang, Atmos. Environ. 40 (2006) 3367.

6. M. Santoso, P.K. Hopke, A. Hidayat and D.D. Lestiani, Sci. Total Environ. 397 (2008) 229.

7. S.K. Biswas, S.A. Tarafdar, A. Islam, M. Khaliquzzaman, H. Tervahattu and K. Kupiainen, Bangladesh. J. Air Waste Manage. Assoc. 53 (2003) 1355.

8. W. Chueinta, P.K. Hopke and P. Paatero, Atmos. Environ. 34 (2000) 3319.

9. B.A. Begum, S.K. Biswas, E. Kim, P.K. Hopke and M. Khaliquzzaman, Bangladesh. J. Air Waste Manage. Assoc. 55 (2005) 227.

10. Y.S. Chung, S.H. Kim, J.H. Moon, Y.J. Kim, J.M. Lim and J.H. Lee, J. Rad. Nucl. Chem. 267 (2005) 35.

11. P.D. Hien, V.T. Bac and N.T.H Thinh, Atmos. Environ. 39 (2005) 7231.

12. W.J. Trompetter and A. Markwitz, Proceeding of 16th Clean Air and Environment Conference (2002).

13. P.K. Hopke, Y. Xie, T. Raunemaa, S.Biegalski, S. Landsberger, W. Maenhaut, P. Artoxo and D. Cohen, Aerosol Sci. Tech. 27 (1997) 726.

14. M. Santoso, A. Hidayat and D.D. Lestiani, Proceeding of the Environmental and Technology Management Conference 2006, Institute of Technology Bandung (2006).

15. J.A. Maxwell, W.J. Teesdale and J.L. Campbell, Nucl. Instrum. Methods Phys. Res. B 95 (1995) 407.

16. I. Salma, W. Maenhaut, H.J. Annegarn, M.O. Andreae, F.X. Meixner and M. Garstang, J. Rad. Nucl. Chem. 216 (1997) 143.

17. R. Zeisler, N. Haselberger, M. Makarewicz, R. Ogis, R.M. Parr, S.F. Stone, O. Valkovic, V. Valkovic and E. Wehrstein, J. Rad. Nucl. Chem. 217 (1997) 5.

18. S.M. Almeida, M.M. Farinha, M.C.Freitas, M. Reis and O. Olivei, Proceeding of BAER conference, November (2001).

19. S.M. Almeida, M.A. Reis, M.C. Freitas and C.A. Pio, Nucl. Instrum. Methods Phys. Res. B 207 (2003) 434.

20. P. Toro and E. Corte, J. Radioanal. Nucl. Chem. 221 (1997) 127. 